\title{
Fisiologi dan Gangguan Keseimbangan Natrium, Kalium dan Klorida serta Pemeriksaan Laboratorium
}

\author{
Rismawati Yaswir, Ira Ferawati
}

\begin{abstract}
Abstrak
Elektrolit adalah senyawa di dalam larutan yang berdisosiasi menjadi partikel yang bermuatan (ion) positif atau negatif. Sebagian besar proses metabolisme memerlukan dan dipengaruhi oleh elektrolit. Konsentrasi elektrolit yang tidak normal dapat menyebabkan banyak gangguan. Pemeliharaan tekanan osmotik dan distribusi beberapa kompartemen cairan tubuh manusia adalah fungsi utama empat elektrolit mayor, yaitu natrium ( $\mathrm{Na}+$ ), kalium (K+), klorida ( $\mathrm{Cl}-$ ), dan bikarbonat (HCO3-). Pemeriksaan keempat elektrolit mayor tersebut dalam klinis dikenal sebagai "profil elektrolit. Natrium adalah kation terbanyak dalam cairan ekstrasel, kalium kation terbanyak dalam cairan intrasel dan klorida merupakan anion terbanyak dalam cairan ekstrasel. Jumlah natrium, kalium dan klorida dalam tubuh merupakan cermin keseimbangan antara yang masuk terutama dari saluran cerna dan yang keluar terutama melalui ginjal. Gangguan keseimbangan natrium, kalium dan klorida berupa hipo- dan hiper-. Hipoterjadi bila konsentrasi elektrolit tersebut dalam tubuh turun lebih dari beberapa miliekuivalen dibawah nilai normal dan hiper- bila konsentrasinya meningkat diatas normal.Pemeriksaan laboratorium untuk menentukan kadar natrium, kalium dan klorida adalah dengan metode elektroda ion selektif, spektrofotometer emisi nyala, spektrofotometer atom serapan, spektrofotometri berdasarkan aktivasi enzim, pemeriksaan kadar klorida dengan metode titrasi merkurimeter, dan pemeriksaan kadar klorida dengan metode titrasi kolorimetrik-amperometrik.
\end{abstract}

Kata kunci: elektrolit, keseimbangan, gangguan keseimbangan

\section{Abstract}

Electrolyte is compound in condensation which is disociation become particle which is charged (ion) negative or positive. Most metabolism processes need and influenced by electrolyte. Electrolyte concentration which abnormal can cause many troubles. Conservancy of osmotic pressure and distribution some human being body fluid compartment are especial function four major electrolyte, that is natrium ( $\mathrm{Na}+)$, potassium (K+), chloride (Cl-), and bicarbonate (HCO3-). Fourth Inspection of the major electrolyte in clinic known as "electrolyte profile". Sodium is cation many in extracell fluid, potassium is cation many in intrasel fluid, and chloride is anion many in extracell fluid. Amount of natrium, chloride and potassium in body are balance which enter especially from digest and excretion especially through kidney.Balance disorders of natrium, chloride and potassium in the form of hipo- and hyper-. Hipo- happened when the electrolyte concentration in body go down more than some miliekuivalen under normal values and hyper- when the concentration of mounting above normal.Laboratory findings to determine concentration of natrium, chloride and potassium are with ion selective electrode (ISE) method, flame emission spectrophotometry (FES), atomic absorption spectrophotometry, spektrofotometry pursuant to enzyme activation, determine concentration of chloride with titration method of merkurimeter, and with titration method of colorimetry-amperometry.

Keywords: Electrolyte, balance, balance disorders

Affiliasi penulis : BAGIAN PATOLOGI KLINIK FK UNAND/RSUP Dr. M. DJAMIL

Korespondensi : Rismawati Yaswir, BAGIAN PATOLOGI KLINIK FK UNAND/RSUP Dr. M. DJAMILJI. Perintis Kemerdekaan Padang Telp/Fax: (0751) 841514E-mail: pdspatklin_pdg@yahoo.com

\section{Pendahuluan}

Elektrolit adalah senyawa di dalam larutan yang berdisosiasi menjadi partikel yang bermuatan (ion) positif atau negatif. Ion bermuatan positif disebut kation dan ion bermuatan negatif disebut anion. Keseimbangan keduanya disebut sebagai elektronetralitas. ${ }^{1-4}$

Sebagian besar proses metabolisme memerlukan dan dipengaruhi oleh elektrolit. Konsentrasi elektrolit yang tidak normal dapat menyebabkan banyak gangguan., ${ }^{1,3-5}$
Pemeliharaan homeostasis cairan tubuh adalah penting bagi kelangsungan hidup semua organisme. Pemeliharaan tekanan osmotik dan distribusi beberapa kompartemen cairan tubuh manusia adalah fungsi utama empat elektrolit mayor, yaitu natrium $\left(\mathrm{Na}^{+}\right)$, kalium $\left(\mathrm{K}^{+}\right)$, klorida $\left(\mathrm{Cl}^{-}\right)$, dan bikarbonat $\left(\mathrm{HCO}_{3}{ }^{-}\right)$. Pemeriksaan keempat elektrolit mayor tersebut dalam klinis dikenal sebagai "profil elektrolit"..

Tinjauan pustaka ini akan membahas tentang fisiologi natrium, kalium dan klorida, gangguan keseimbangan serta pemeriksaan laboratoriumnya.

\section{Fisiologi Natrium, Kalium Dan Klorida}

Cairan tubuh terdiri dari air dan elektrolit. Cairan tubuh dibedakan atas cairan ekstrasel dan intrasel. Cairan ekstrasel meliputi plasma dan cairan 
interstisial. Distribusi elektrolit pada cairan intrasel dan ekstrasel dapat dilihat pada Gambar 1.,4,6-7

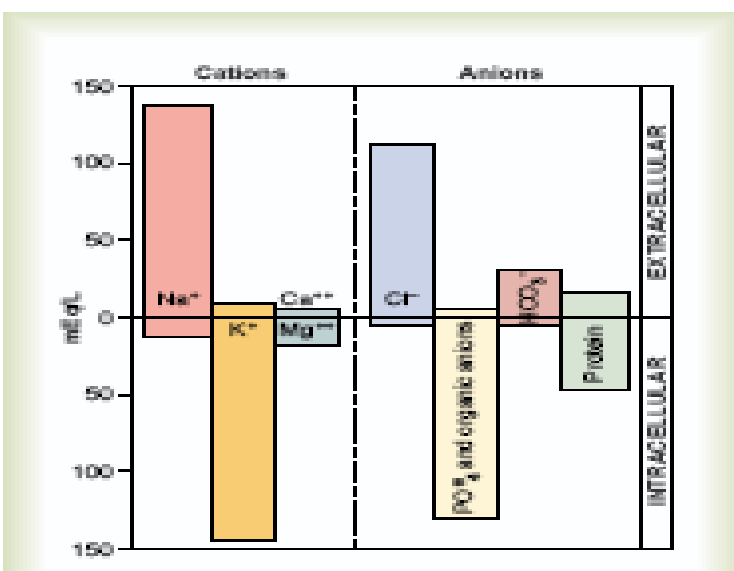

Gambar 1. Kation dan Anion Utama dalam Cairan Intrasel dan Ekstrasel ${ }^{6}$

\section{Fisiologi Natrium}

Natrium adalah kation terbanyak dalam cairan ekstrasel, jumlahnya bisa mencapai $60 \mathrm{mEq}$ per kilogram berat badan dan sebagian kecil (sekitar 10$14 \mathrm{mEq} / \mathrm{L})$ berada dalam cairan intrasel ${ }^{4,8}$. Lebih dari $90 \%$ tekanan osmotik di cairan ekstrasel ditentukan oleh garam yang mengandung natrium, khususnya dalam bentuk natrium klorida $(\mathrm{NaCl})$ dan natrium bikarbonat (NaHCO3) sehingga perubahan tekanan osmotik pada cairan ekstrasel menggambarkan perubahan konsentrasi natrium ${ }^{3}$.

Perbedaan kadar natrium intravaskuler dan interstitial disebabkan oleh keseimbangan GibbsDonnan, sedangkan perbedaan kadar natrium dalam cairan ekstrasel dan intrasel disebabkan oleh adanya transpor aktif dari natrium keluar sel yang bertukar dengan masuknya kalium ke dalam sel (pompa $\mathrm{Na}^{+}$ $\left.\mathrm{K}^{+}\right)^{2,4,9-10}$. Kadar natrium dalam cairan ekstrasel dan cairan intrasel dapat dilihat pada Tabel $1^{3}$.

Jumlah natrium dalam tubuh merupakan gambaran keseimbangan antara natrium yang masuk dan natrium yang dikeluarkan. Pemasukan natrium yang berasal dari diet melalui epitel mukosa saluran cerna dengan proses difusi dan pengeluarannya melalui ginjal atau saluran cerna atau keringat di kulit. $^{3-5,11-12}$. Pemasukan dan pengeluaran natrium perhari mencapai 48-144 mEq. ${ }^{3}$

Tabel 1. Kadar Elektrolit dalam Cairan Ekstrasel dan Intrasel $^{3}$

\begin{tabular}{llll}
\hline & $\begin{array}{l}\text { Plasma } \\
\mathrm{mEq} / \mathrm{L}\end{array}$ & $\begin{array}{l}\text { Cairan } \\
\text { Interstitial } \\
\mathrm{mEq} / \mathrm{L}\end{array}$ & $\begin{array}{l}\text { Cairan } \\
\text { Intraseluler } \\
\mathrm{mEq} / \mathrm{L}\end{array}$ \\
\hline $\mathrm{Na}^{+}$ & 140 & 148 & 13 \\
$\mathrm{~K}^{+}$ & 4,5 & 5,0 & 140 \\
$\mathrm{Ca}^{2+}$ & 5,0 & 4,0 & $1 \times 10^{-7}$ \\
$\mathrm{Mg}^{2+}$ & 1,7 & 1,5 & 7,0 \\
$\mathrm{Cl}^{-}$ & 104 & 115 & 3,0 \\
$\mathrm{HCO}_{3}$ & 24 & 27 & 10 \\
$\mathrm{SO}_{4}{ }^{2+}$ & 1,0 & 1,2 & -- \\
$\mathrm{PO}_{4}{ }^{2-}$ & 2,0 & 2,3 & 107 \\
$\mathrm{Protein}_{\text {Anion Organik }}$ & 15 & 8 & 40 \\
\hline
\end{tabular}

Jumlah natrium yang keluar dari traktus gastrointestinal dan kulit kurang dari 10\%. Cairan yang berisi konsentrasi natrium yang berada pada saluran cerna bagian atas hampir mendekati cairan ekstrasel, namun natrium direabsorpsi sebagai cairan pada saluran cerna bagian bawah, oleh karena itu konsentrasi natrium pada feses hanya mencapai 40 $\mathrm{mEq} / \mathrm{L}^{4}$.

Keringat adalah cairan hipotonik yang berisi natrium dan klorida. Kandungan natrium pada cairan keringat orang normal rerata $50 \mathrm{mEq} / \mathrm{L}$. Jumlah pengeluaran keringat akan meningkat sebanding dengan lamanya periode terpapar pada lingkungan yang panas, latihan fisik dan demam ${ }^{1,4}$.

Ekskresi natrium terutama dilakukan oleh ginjal. Pengaturan eksresi ini dilakukan untuk mempertahankan homeostasis natrium, yang sangat diperlukan untuk mempertahankan volume cairan tubuh. Natrium difiltrasi bebas di glomerulus, direabsorpsi secara aktif $60-65 \%$ di tubulus proksimal bersama dengan $\mathrm{H}_{2} \mathrm{O}$ dan klorida yang direabsorpsi secara pasif, sisanya direabsorpsi di lengkung henle (25-30\%), tubulus distal (5\%) dan duktus koligentes $(4 \%)$. Sekresi natrium di urine $<1 \%$. Aldosteron menstimulasi tubulus distal untuk mereabsorpsi natrium bersama air secara pasif dan mensekresi kalium pada sistem renin-angiotensin-aldosteron untuk mempertahankan elektroneutralitas. ${ }^{9,11,13-17}$

\section{Nilai Rujukan Natrium ${ }^{5,18}$}

Nilai rujukan kadar natrium pada:

$$
\begin{array}{ll}
\text { - serum bayi } & : 134-150 \mathrm{mmol} / \mathrm{L} \\
\text { - serum anak dan dewasa } & : 135-145 \mathrm{mmol} / \mathrm{L} \\
\text { - urine anak dan dewasa } & : 40-220 \mathrm{mmol} / 24 \mathrm{jam} \\
\text { - cairan serebrospinal } & : 136-150 \mathrm{mmol} / \mathrm{L} \\
\text { - feses } & : \text { kurang dari } 10 \mathrm{mmol} / \mathrm{hari}
\end{array}
$$

\section{Fisiologi Kalium}

Sekitar 98\% jumlah kalium dalam tubuh berada di dalam cairan intrasel. Konsentrasi kalium intrasel sekitar $145 \mathrm{mEq} / \mathrm{L}$ dan konsentrasi kalium ekstrasel $\quad 4-5 \mathrm{mEq} / \mathrm{L}$ (sekitar 2\%). Jumlah konsentrasi kalium pada orang dewasa berkisar 50-60 per kilogram berat badan (3000-4000 mEq). Jumlah kalium ini dipengaruhi oleh umur dan jenis kelamin. Jumlah kalium pada wanita $25 \%$ lebih kecil dibanding pada laki-laki dan jumlah kalium pada orang dewasa lebih kecil $20 \%$ dibandingkan pada anak-anak. ${ }^{19}$

Perbedaan kadar kalium di dalam plasma dan cairan interstisial dipengaruhi oleh keseimbangan Gibbs-Donnan, sedangkan perbedaan kalium cairan intrasel dengan cairan interstisial adalah akibat adanya transpor aktif (transpor aktif kalium ke dalam sel bertukar dengan natrium). ${ }^{19-20}$

Jumlah kalium dalam tubuh merupakan cermin keseimbangan kalium yang masuk dan keluar. Pemasukan kalium melalui saluran cerna tergantung dari jumlah dan jenis makanan. Orang dewasa pada keadaan normal mengkonsumsi 60-100 mEq kalium perhari (hampir sama dengan konsumsi natrium). Kalium difiltrasi di glomerulus, sebagian besar (70$80 \%$ ) direabsorpsi secara aktif maupun pasif di tubulus proksimal dan direabsorpsi bersama dengan natrium dan klorida di lengkung henle. ${ }^{19-20}$ Kalium dikeluarkan dari tubuh melalui traktus gastrointestinal kurang dari $5 \%$, kulit dan urine mencapai $90 \%$. $^{13,19-20}$ 
Nilai Rujukan Kalium ${ }^{5,18}$

Nilai rujukan kalium serum pada:

- serum bayi

: 3,6-5,8 $\mathrm{mmol} / \mathrm{L}$

- serum anak

$3,5-5,5 \mathrm{mmo} / \mathrm{L}$

- serum dewasa

$3,5-5,3 \mathrm{mmol} / \mathrm{L}$

$17-57 \mathrm{mmol} / 24 \mathrm{jam}$

urine anak

$40-80 \mathrm{mmol} / 24 \mathrm{jam}$

- urine dewasa

- cairan lambung

: $10 \mathrm{mmol} / \mathrm{L}$

\section{Fisiologi Klorida}

Klorida merupakan anion utama dalam cairan ekstrasel. Pemeriksaan konsentrasi klorida dalam plasma berguna sebagai diagnosis banding pada gangguan keseimbangan asam-basa, dan menghitung anion gap. ${ }^{14}$

Jumlah klorida pada orang dewasa normal sekitar $30 \mathrm{mEq}$ per kilogram berat badan. Sekitar $88 \%$ klorida berada dalam cairan ekstraseluler dan $12 \%$ dalam cairan intrasel. Konsentrasi klorida pada bayi lebih tinggi dibandingkan pada anak-anak dan dewasa. $^{20}$

Keseimbangan

Gibbs-Donnan mengakibatkan kadar klorida dalam cairan interstisial lebih tinggi dibanding dalam plasma. Klorida dapat menembus membran sel secara pasif. ${ }^{11}$ Perbedaan kadar klorida antara cairan interstisial dan cairan intrasel disebabkan oleh perbedaan potensial di permukaan luar dan dalam membran sel. ${ }^{15}$

Jumlah klorida dalam tubuh ditentukan oleh keseimbangan antara klorida yang masuk dan yang keluar. Klorida yang masuk tergantung dari jumlah dan jenis makanan. Kandungan klorida dalam makanan sama dengan natrium. Orang dewasa pada keadaan normal rerata mengkonsumsi 50-200 mEq klorida per hari, dan ekskresi klorida bersama feses sekitar 1-2 $\mathrm{mEq}$ perhari. Drainase lambung atau usus pada diare menyebabkan ekskresi klorida mencapai $100 \mathrm{mEq}$ perhari. Kadar klorida dalam keringat bervariasi, rerata $40 \mathrm{mEq} / \mathrm{L}$. Bila pengeluaran keringat berlebihan, kehilangan klorida dapat mencapai $200 \mathrm{mEq}$ per hari. Ekskresi utama klorida adalah melalui ginjal. ${ }^{1,4,20}$

Nilai Rujukan Klorida ${ }^{5,18}$

- serum bayi baru lahir

: $94-112 \mathrm{mmol} / \mathrm{L}$

- serum anak

: $98-105 \mathrm{mmol} / \mathrm{L}$

- serum dewasa

- keringat anak

- keringat dewasa

$95-105 \mathrm{mmol} / \mathrm{L}$

$:<50 \mathrm{mmol} / \mathrm{L}$

$:<60 \mathrm{mmol} / \mathrm{L}$

: $110-250 \mathrm{mmol} / 24 \mathrm{jam}$

- feses

: $2 \mathrm{mmol} / 24 \mathrm{jam}$

\section{GANGGUAN KESEIMBANGAN NATRIUM, KALIUM DAN KLORIDA}

\section{Gangguan Keseimbangan Natrium}

Seseorang dikatakan hiponatremia, bila konsentrasi natrium plasma dalam tubuhnya turun lebih dari beberapa miliekuivalen dibawah nilai normal (135-145 mEq/L) dan hipernatremia bila konsentrasi natrium plasma meningkat di atas normal. Hiponatremia biasanya berkaitan dengan hipoosmolalitas dan hipernatremia berkaitan dengan hiperosmolalitas. $8,10,12$

\section{Penyebab Hiponatremia}

Kehilangan natrium klorida pada cairan ekstrasel atau penambahan air yang berlebihan pada cairan ekstrasel akan menyebabkan penurunan konsentrasi natrium plasma. Kehilangan natrium klorida primer biasanya terjadi pada dehidrasi hipo- osmotik seperti pada keadaan berkeringat selama aktivitas berat yang berkepanjangan, berhubungan dengan penurunan volume cairan ekstrasel seperti diare, muntah-muntah, dan penggunaan diuretik secara berlebihan. ${ }^{10,12,19}$

Hiponatremia juga dapat disebabkan oleh beberapa penyakit ginjal yang menyebabkan gangguan fungsi glomerulus dan tubulus pada ginjal, penyakit addison, serta retensi air yang berlebihan (overhidrasi hipo-osmotik) akibat hormon antidiuretik $^{10,12,19}$. Kepustakaan lain menyebutkan bahwa respons fisiologis dari hiponatremia adalah tertekannya pengeluaran $\mathrm{ADH}$ dari hipotalamus (osmolaritas urine rendah).,

Pseudohiponatremia dapat dijumpai pada penurunan fraksi plasma, yaitu pada kondisi hiperlipidemia dan hiperkolesterolemia, hiperproteinemia dan hiperglikemia serta kelebihan pemberian manitol dan glisin. ${ }^{19}$

\section{Penyebab Hipernatremia}

Peningkatan konsentrasi natrium plasma karena kehilangan air dan larutan ekstrasel (dehidrasi hiperosmotik pada diabetes insipidus) atau karena kelebihan natrium dalam cairan ekstrasel seperti pada overhidrasi osmotik atau retensi air oleh ginjal dapat menyebabkan peningkatan osmolaritas \& konsentrasi natrium klorida dalam cairan ekstrasel. ${ }^{19}$

Kepustakaan lain menyebutkan bahwa hipernatremia dapat terjadi bila ada defisit cairan tubuh akibat ekskresi air melebihi ekskresi natrium atau asupan air yang kurang. Misalnya pada pengeluaran air tanpa elektrolit melalui insensible water loss atau keringat, diare osmotik akibat pemberian laktulose atau sorbitol, diabetes insipidus sentral maupun nefrogenik, diuresis osmotik akibat glukosa atau manitol, gangguan pusat rasa haus di hipotalamus akibat tumor atau gangguan vaskular.,

\section{Gangguan Keseimbangan Kalium}

Bila kadar kalium kurang dari $3,5 \mathrm{mEq} / \mathrm{L}$ disebut sebagai hipokalemia dan kadar kalium lebih dari 5,3 $\mathrm{mEq} / \mathrm{L}$ disebut sebagai hiperkalemia. Kekurangan ion kalium dapat menyebabkan frekuensi denyut jantung melambat. ${ }^{3,10,16,19}$ Peningkatan kalium plasma 3-4 $\mathrm{mEq} / \mathrm{L}$ dapat menyebabkan aritmia jantung, konsentrasi yang lebih tinggi lagi dapat menimbulkan henti jantung atau fibrilasi jantung.,10

\section{Penyebab Hipokalemia}

Penyebab hipokalemia dapat dibagi sebagai berikut :

a. Asupan Kalium Kurang

Orang tua yang hanya makan roti panggang dan teh, peminum alkohol yang berat sehingga jarang makan dan tidak makan dengan baik, atau pada pasien sakit berat yang tidak dapat makan dan minum dengan baik melalui mulut atau disertai oleh masalah lain misalnya pada pemberian diuretik atau pemberian diet rendah kalori pada program menurunkan berat badan dapat menyebabkan hipokalemia. ${ }^{1,3,7,10}$

\section{b. Pengeluaran Kalium Berlebihan}

Pengeluaran kalium yang berlebihan terjadi melalui saluran cerna seperti muntah-muntah, melalui ginjal seperti pemakaian diuretik, kelebihan hormon mineralokortikoid primer/hiperaldosteronisme primer (sindrom bartter 
atau sindrom gitelman) atau melalui keringat yang berlebihan. ${ }^{3,7,10}$

Diare, tumor kolon (adenoma vilosa) dan pemakaian pencahar menyebabkan kalium keluar bersama bikarbonat pada saluran cerna bagian bawah (asidosis metabolik). ${ }^{1,3}$ Licorice (semacam permen) yang mengandung senyawa yang bekerja mirip aldosteron, dapat menyebabkan hipokalemia jika dimakan berlebihan. ${ }^{1}$

c. Kalium Masuk ke Dalam Sel

Kalium masuk ke dalam sel dapat terjadi pada alkalosis ekstrasel, pemberian insulin, peningkatan aktivitas beta-adrenergik (pemakaian $\beta 2$ - agonis), paralisis periodik hipokalemik, dan hipotermia.

\section{Penyebab Hiperkalemia}

Hiperkalemia dapat disebabkan oleh :

a. Keluarnya Kalium dari Intrasel ke Ekstrasel

Kalium keluar dari sel dapat terjadi pada keadaan asidosis metabolik bukan oleh asidosis organik (ketoasidosis, asidosis laktat), defisit insulin, katabolisme jaringan meningkat, pemakaian obat penghambat- $\beta$ adrenergik, dan pseudohiperkalemia. ${ }^{3,10}$

b. Berkurangnya Ekskresi Kalium melalui Ginjal Berkurangnya ekskresi kalium melalui ginja terjadi pada keadaan hiperaldosteronisme, gagal ginjal, deplesi volume sirkulasi efektif, pemakaian siklosporin atau akibat koreksi ion kalium berlebihan dan pada kasus-kasus yang mendapat terapi angiotensin-converting enzyme inhibitor dan potassium sparing diuretics. $3,7,10$

Pseudohiperkalemia dapat disebabkan oleh hemolisis, sampel tidak segera diperiksa atau akibat kesalahan preanalitik yang lain yaitu tornikuet pada lengan atas tidak dilepas sebelum diambil darah setelah penderita menggenggam tangannya berulangkali (peningkatan sampai $2 \mathrm{mmol} / \mathrm{L}$ ). Jumlah trombosit $>500.000 / \mathrm{mm}^{3}$ atau leukosit $>70.000 / \mathrm{mm}^{3}$ juga dapat meningkatkan kadar kalium serum. ${ }^{14}$

\section{Gangguan Keseimbangan Klorida Penyebab Hipoklorinemia}

Hipoklorinemia terjadi jika pengeluaran klorida melebihi pemasukan. Penyebab hipoklorinemia umumnya sama dengan hiponatremia, tetapi pada alkalosis metabolik dengan hipoklorinemia, defisit klorida tidak disertai defisit natrium. Hipoklorinemia juga dapat terjadi pada gangguan yang berkaitan dengan retensi bikarbonat, contohnya pada asidosis respiratorik kronik dengan kompensasi ginjal. ${ }^{14}$

\section{Penyebab Hiperklorinemia}

Hiperklorinemia terjadi jika pemasukan melebihi pengeluaran pada gangguan mekanisme homeostasis dari klorida. Umumnya penyebab hiperklorinemia sama dengan hipernatremia. Hiperklorinemia dapat dijumpai pada kasus dehidrasi, asidosis tubular ginjal, gagal ginjal akut, asidosis metabolik yang disebabkan karena diare yang lama dan kehilangan natrium bikarbonat, diabetes insipidus, hiperfungsi status adrenokortikal dan penggunaan larutan salin yang berlebihan, alkalosis respiratorik. Asidosis hiperklorinemia dapat menjadi petanda pada gangguan tubulus ginjal yang luas. ${ }^{14}$

\section{Pemeriksaan Laboratorium \\ Bahan Pemeriksaan}

Pemeriksaan dapat dilakukan pada sampel whole blood, plasma, serum, urine, keringat, feses, dan cairan tubuh. Pemeriksaan pada whole blood biasanya dilakukan bersama dengan pemeriksaan $\mathrm{pH}$ dan gas darah dan harus segera diperiksa (kurang dari 1 jam). Sampel serum, plasma atau urine dapat disimpan pada refrigerator dalam tabung tertutup pada suhu $2^{\circ} \mathrm{C}-8^{0} \mathrm{C}$ dan dihangatkan kembali pada suhu ruangan $\left(15^{\circ} \mathrm{C}-30^{\circ} \mathrm{C}\right)$ sebelum diperiksa. ${ }^{14}$ Sampel feses harus cair, disaring dan diputar (sentrifugasi) sebelum dilakukan pemeriksaan. ${ }^{5,14}$

\section{Metode Pemeriksaan}

\section{Pemeriksaan dengan Metode Elektroda} Ion Selektif (Ion Selective Electrode/SE)

Pemeriksaan kadar natrium, kalium, dan klorida dengan metode elektroda ion selektif (Ion Selective Electrode/SE) adalah yang paling sering digunakan. Data dari College of American Pathologists (CAP) pada 5400 laboratorium yang memeriksa natrium dan kalium, lebih dari 99\% menggunakan metode ISE. Metode ISE mempunyai akurasi yang baik, koefisien variasi kurang dari 1,5\%, kalibrator dapat dipercaya dan mempunyai program pemantapan mutu yang baik. $^{14}$

ISE ada dua macam yaitu ISE direk dan ISE indirek. ISE direk memeriksa secara langsung pada sampel plasma, serum dan darah utuh. Metode inilah yang umumnya digunakan pada laboratorium gawat darurat. Metode ISE indirek yang diberkembang lebih dulu dalam sejarah teknologi ISE, yaitu memeriksa sampel yang sudah diencerkan. ${ }^{14}$

- Prinsip Pengukuran

Pada dasarnya alat yang menggunakan metode ISE untuk menghitung kadar ion sampel dengan membandingkan kadar ion yang tidak diketahui nilainya dengan kadar ion yang diketahui nilainya. Membran ion selektif pada alat mengalami reaksi dengan elektrolit sampel. Membran merupakan penukar ion, bereaksi terhadap perubahan listrik ion sehingga menyebabkan perubahan potensial membran. Perubahan potensial membran ini diukur, dihitung menggunakan persamaan Nerst, hasilnya kemudian dihubungkan dengan amplifier dan ditampilkan oleh alat ${ }^{20}$. Proses ini dapat dilihat pada Gambar 2. ${ }^{20}$

Salah satu persamaan Nernst yang dipakai yaitu::20

$$
E=E^{\prime}=\frac{R \cdot T}{n \cdot F} \cdot 1 n(f 1-c 1)
$$

(+) untuk kation (-) untuk anion

$E=$ Potensial elektrik yang diukur

$E^{\prime}=$ Sistem e.m.f pada larutan standar

$\mathrm{R}=$ Konstanta Gas $(8,31 \mathrm{~J} / \mathrm{Kmol})$

$\mathrm{T}=$ Suhu

$\mathrm{n}=$ Valensi ion yang diukur

$\mathrm{F}=$ Konstanta Faraday 96,496 A.s/g

$\mathrm{f} 1=$ Koefisien aktivitas

$\mathrm{c} 1=$ Konsentrasi ion yang diukur 


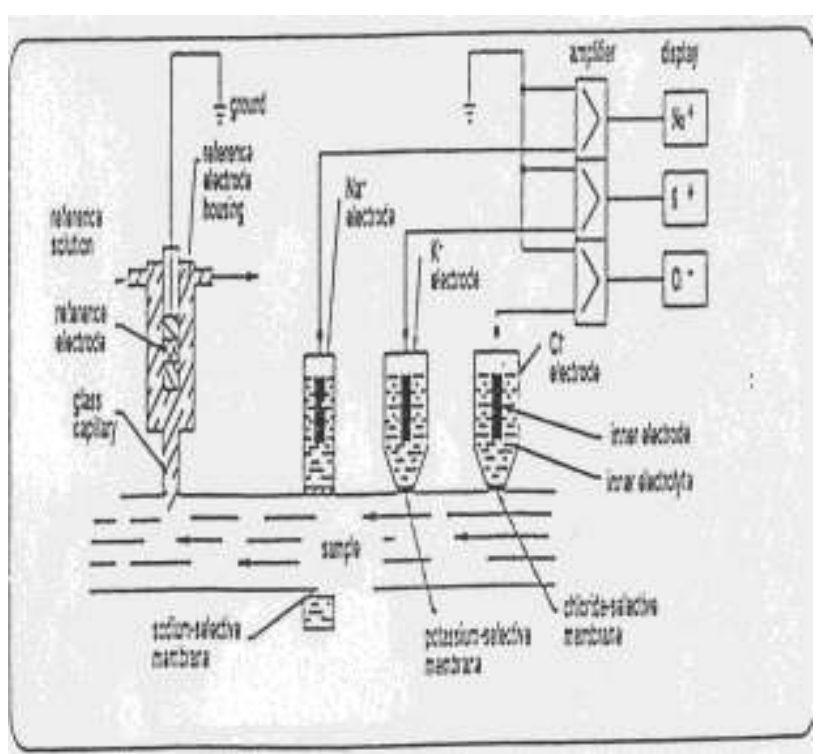

Gambar 2. Prinsip Pengukuran Elektrolit dengan Metode ISE. ${ }^{20}$

\section{Pemeriksaan dengan Spektrofotometer Emisi Nyala (Flame Emission Spectrofotometry/FES)}

Spektrofotometer emisi nyala digunakan untuk pengukuran kadar natrium dan kalium. Penggunaan spektrofotometer emisi nyala di laboratorium berlangsung tidak lama, selanjutnya penggunaannya dikombinasi dengan elektrokimia untuk mempertahankan penggunaan dan keamanan prosedurnya. $^{14}$

Prinsip pemeriksaan spektrofotometer emisi nyala adalah sampel diencerkan dengan cairan pengencer yang berisi litium atau cesium, kemudian dihisap dan dibakar pada nyala gas propan. Ion natrium, kalium, litium, atau sesium bila mengalami pemanasan akan memancarkan cahaya dengan panjang gelombang tertentu (natrium berwarna kuning dengan panjang gelombang $589 \mathrm{~nm}$, kalium berwarna ungu dengan panjang gelombang $768 \mathrm{~nm}$, litium $671 \mathrm{~nm}$, sesium $825 \mathrm{~nm})$. Pancaran cahaya akibat pemanasan ion dipisahkan dengan filter dan dibawa ke detektor sinar. $^{14}$

\section{Pemeriksaan dengan Spektrofotometer berdasarkan Aktivasi Enzim}

Prinsip pemeriksaan kadar natrium dengan metode spektrofotometer yang berdasarkan aktivasi enzim yaitu aktivasi enzim beta-galaktosidase oleh ion natrium untuk menghidrolisis substrat 0 -nitrophenyl- $\beta$ $D$-galaktipyranoside (ONPG). Jumlah galaktosa dan onitrofenol yang terbentuk diukur pada panjang gelombang $420 \mathrm{~nm}^{14}$

Prinsip pemeriksaan kalium dengan metode spektrofotometer adalah ion $\mathrm{K}^{+}$mengaktivasi enzim tryptophanase. $^{14}$

Prinsip pemeriksaan klorida dengan metode spektrofotometer adalah reaksi klorida dengan merkuri thiosianat menjadi merkuri klorida dan ion thiosianat. Ion thiosianat bereaksi dengan ion ferri dan dibaca pada panjang gelombang $480 \mathrm{~nm}^{14}$

4. Pemeriksaan dengan spektrofotometer atom serapan (Atomic Absorption Spectrophotometry/ AAS)

Prinsip pemeriksaan dengan spektrofotometer atom serapan adalah teknik emisi dengan elemen pada sampel mendapat sinar dari hollow cathode dan cahaya yang ditimbulkan diukur sebagai level energi yang paling rendah. Elemen yang mendapat sinar dalam bentuk ikatan kimia (atom) dan ditempatkan pada ground state (atom netral). Metode spektrofotometer atom serapan mempunyai sensitivitas spesifisitas yang lebih tinggi dibandingkan metode spektrofotometer nyala emisi. ${ }^{28}$

\section{Pemeriksaan Kadar Klorida dengan Metode} Titrasi Merkurimeter

Prinsip: Spesimen filtrat yang bebas protein dititrasi dengan larutan merkuri nitrat, dengan penambahan diphenylcarbazone sebagai indikator. $\mathrm{Hg}^{2+}$ yang bebas, bersama klorida membentuk larutan merkuri klorida yang tidak terionisasi ${ }^{14}$. Kelebihan ion $\mathrm{Hg}^{2+}$ bereaksi dengan diphenylcarbazone membentuk senyawa kompleks berwarna biru-ungu. Titik akhir dari titrasi adalah saat mulai timbul perubahan warna. ${ }^{14}$

\section{Pemeriksaan Kadar Klorida dengan Metode Titrasi Kolorimetrik-Amperometrik}

Prinsip pemeriksaan kadar klorida dengan metode titrasi kolorimetrik-amperometrik bergantung pada generasi $\mathrm{Ag}^{+}$dari elektroda perak yang konstan dan pada reaksi dengan klorida membentuk klorida perak tang tidak larut. Interval waktu yang digunakan sebanding dengan kadar klorida pada sampel.

\section{Daftra Pustaka}

1. Wilson L.M, 'Keseimbangan Cairan dan Elektrolit serta Penilaiannya' dalam: Patofisiologi Konsep Klinis Proses-proses Penyakit, Edisi ke-4, Penerbit Buku Kedokteran EGC, Jakarta, 1995, hh. 283301.

2. Sacher R.A. dan Mcpherson R.A 'Pengaturan Asam-Basa dan Elektrolit' pada: Tinjauan Klinis Hasil Pemeriksaan Laboratorium, edisi kedua, Penerbit Buku Kedokteran EGC, Jakarta, 2002, hh.320-340.

3. Darwis D, Moenajat Y, Nur B.M, Madjid A.S, Siregar $\mathrm{P}$, Aniwidyaningsih $\mathrm{W}$, dkk, 'Fisiologi Keseimbangan Air dan Elektrolit' dalam Gangguan Keseimbangan Air-Elektrolit dan Asam-Basa, Fisiologi, Patofisiologi, Diagnosis dan Tatalaksana, ed. ke-2, FK-UI, Jakarta, 2008, hh. 29-114.

4. Matfin G. and Porth C.M, 'Disorders of Fluid and Electrolyte Balance' In: Pathophysiology Concepts of Altered Health States, $8^{\text {th }}$ Edition, McGraw Hill Companies USA, 2009, pp. 761-803.

5. Scott M.G., LeGrys, V.A. and Klutts J, 'Electrochemistry and Chemical Sensors and Electrolytes and Blood Gases" In: Tietz Text Book of Clinical Chemistry and Molecular Diagnostics, $4^{\text {th }}$ Ed. Vol.1, Elsevier Saunders Inc., Philadelphia, 2006, pp. 93-1014.

6. Guyton A.C and Hall J.E, dalam: Buku Ajar Fisiologi Kedokteran Edisi ke-11, Penerbit Buku Kedokteran EGC, Jakarta, 2008, hh. 307-400.

7. Siregar $P$, 'Gangguan Keseimbangan Cairan dan Elektrolit' dalam: Buku Ajar IImu Penyakit Dalam, Edisi ke-5, Interna publishing, Jakarta, 2009, hh. 175-189.

8. O'Callaghan C, 'Sains Dasar Ginjal dan Gangguan Fungsi Metabolik Ginjal' At a Glance Sistem Ginjal, Edisi Kedua, Penerbit Erlangga, Jakarta, 2009, hh. 22-68. 
9. Stefan Silbernagl and Florian Lang, Teks dan Atlas Berwarna Patofisiologi, Penerbit Buku Kedokteran EGC, 2007, hh. 92-125.

10. Fischbach F, Dunning M.B, Talaska F, Barnet $M$, Schweitzer T.A, Strandell C, et al, 'Chlorida, Potassium, Sodium' In: A Manual of Laboratory and Diagnostic Test, $8^{\text {th }}$ Ed., Lippincot Wiliams and Wilkins, 2009, pp. 9971009.

11. Widmaier E.P, Raff H. dan Strang K.T, 'The Kidney and Regulation of Water and Inorganic lons' In: Vander Human Physiology: The Mechanisms of Body Function, $9^{\text {th }}$ Edition, McGraw Hill Publishing, 2004, pp. 513-557.

12. Singer G.G and Brenner B.M, 'Fluid and Electrolyte Disturbances' In: Harrison's Principles of Internal Medicine, $17^{\text {th }}$ Ed., Vol. 1, McGraw Hill Companies USA, 2008, pp. 274-287.

13. Ganong W.F, 'Fungsi Ginjal dan Miksi' pada Buku Ajar Fisiologi Kedokteran, edisi ke-22, Penerbit Buku Kedokteran EGC, Jakarta, 2005, hh. 725-756.

14. Klutts J.S. and Scott M.G, 'Physiology and disorders of Water, Electrolyte, and AcidBase Metabolism' In: Tietz Text Book of Clinical Chemistry and Molecular Diagnostics, $4^{\text {th }}$ Ed. Vol.1, Elsevier Saunders Inc., Philadelphia, 2006, pp. 1747-1775.
15. Eaton D.C. and Pooler J.P, in: Vander's Renal Physiology, $7^{\text {th }}$ Ed, McGraw Hill Companies Inc. Atlanta, 2009, pp. 77-154.

16. Emmett M. and Mederkehr M.K, 'Disorders of Potassium Balance: Hipokalemia and Hyperkalemia' In: Lange Current Diagnosis and Treatment Nephrology and Hypertension, McGraw Hill Companies Inc, 2009, pp. 3241.Sherwood L, 'The Urinary System' In: Human Physiology from cells to systems, $7^{\text {th }}$ Ed. Brooks/Cole, USA, 2010, pp. 510-557.

17. Kee J.L,'Uji Laboratorium' dalam: Pedoman Pemeriksaan Laboratorium dan Diagnostik, Edisi ke-6, Penerbit Buku Kedokteran EGC, Jakarta, 2003, hh. 1-484.

18. Reilly R.F and Perazella M.A, In: Lange AcidBase Fluids and Electrolytes, McGraw Hill Companies Inc.USA, 2007, pp. 21-170.

19. Priest G, Smith B and Heitz, ' 9180 Electrolyte Analyzer Operator's Manual' $1^{\text {st }} \mathrm{Ed}$, AVL Scientifi Corporation, USA, 1996, pp. 1-120. 